\title{
Agenda Setting in Water and IWRM: Discourse Analysis of Water Policy Debate in Pakistan
}

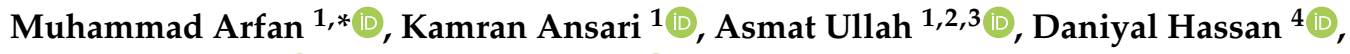 \\ Altaf Ali Siyal ${ }^{1,5}\left(\mathbb{D}\right.$ and Shaofeng Jia ${ }^{6, * \mathbb{C}}$ \\ 1 US-Pakistan Center for Advanced Studies in Water, MUET, Jamshoro 76090, Pakistan; \\ kansari.uspcasw@faculty.muet.edu.pk (K.A.); asmat.ait@gmail.com (A.U.); siyal@yahoo.com (A.A.S.) \\ 2 The Joint Graduate School of Energy and Environment (JGSEE), \\ King Mongkut's University of Technology Thonburi (KMUTT), 126 Pracha Uthit Road, \\ Bangkok 10140, Thailand \\ 3 Center of Excellence on Energy Technology and Environment, PERDO, Ministry of Higher Education, \\ Science, Research and Innovation, Bangkok 10140, Thailand \\ 4 Department of Civil \& Environmental Engineering, University of Utah, Salt Lake City, UT 84112, USA; \\ daniyalhassan109@gmail.com \\ 5 Faculty of Agricultural Engineering, Sindh Agriculture University, Tandojam, Sindh 70060, Pakistan \\ 6 Key Laboratory of Water Cycle and Related Land Surface Processes/Institute of Geographical Sciences and \\ Natural Resources Research, Chinese Academy of Sciences, Beijing 100101, China \\ * Correspondence: jiasf@igsnrr.ac.cn (S.J.); mapiish37@gmail.com (M.A.)
}

Received: 24 April 2020; Accepted: 28 May 2020; Published: 10 June 2020

check for updates

\begin{abstract}
This article explores the water policy narrative in Pakistan, and identifies its historical trajectories and influences, as well as the impact of the global agenda setting of water for 2030. For this purpose, water sector reforms in Pakistan are examined as a case study. The National Water Policy (NWP) 2018 and Participatory Irrigation Management (PIM) reforms are critically evaluated and loopholes identified, in terms of both theoretical aspects and constraints in their practical implementation. The overall analysis reveals that the engineering narrative is dominant in policy circles and large-scale infrastructure construction is seen as an exceptional measure to overcome the current loss of storage potential due to sedimentation. On the other hand, the adoption of the Integrated Water Resource Management (IWRM) framework reflects the desire of state institutions to imbue water policy reform with international credibility. The IWRM framework has been adopted as isomorphic mimicry to appease international financing institutions and donors. PIM reform is thus far from delivering the desired results due to ideological battles among new (i.e., the Participatory Farmers Institution) and traditional bureaucratic irrigation institutions. As adopted, the global agenda setting of water, in the shape of IWRM, is a repackaging of existing activities, and prevents alternative thinking in the setting of water priorities according to developmental needs.
\end{abstract}

Keywords: National Water Policy; discourse analysis; Integrated Water Resource Management; isomorphic mimicry; path dependency and lock-in; Pakistan

\section{Introduction}

The policy debate on water resource development becomes more urgent as water scarcity becomes acute. The word "policy" can be defined as "a set of ideas or a plan of what to do in particular situations that has been agreed to officially by a group of people, a business organization, a government, or a political party" [1]. Water policy is shaped by theoretical policy discourse. Multiple discourses, critical of each other, exist in water resource development. The primary divisions of the existing 
water narrative can be drawn in terms of the pre-industrial era, industrial development and the era of colonization, and modern cultural development [2].

The pre-industrial era was characterized by localized subsistence economies-“"Asiatic modes of production" [3] —in existence on river plains [4]. This era can be identified by a limited use of water for agriculture, and dominantly pastoral livelihoods with a nomadic lifestyle $[5,6]$. The industrial era is recognized as an era of modern state formation and large-scale irrigation infrastructure expansion, mainly for agriculture [7-9]. Construction of large-scale irrigation infrastructure (barrages, dams, etc.) facilitated an agricultural expansion in areas distant from main river courses. Karl Wittfogel theorized this phenomenon as "hydraulic societies" and a centralized bureaucratic despotic type of state; he termed it "oriental despotism" [7]. Wittfogel's inquiry of hydraulic societies-mainly those of China and Russia - and his theory of Oriental despotic state formation initiated a heated academic debate about the ideological legitimacy of hydraulic bureaucracies [7,10]. During the 19th century, "hydraulic missions" initiated global colonization, both internally and externally. Thereafter, political ecologists [11-13] began to scrutinize the Water Resource Development (WRM) discourse-introduced by the hydraulic bureaucracy - of the 19th and 20th centuries. A critical assessment of the 20th century gave birth to a cultural development in the social sciences. The critical theory of post-structuralism and ecological movements provided a theoretical foundation for the radical rejection of development dilemmas (dilemmas produced due to the negative consequences of modern development) known as "anti-development", "beyond development", and "post-development". This loose consensus rejected the 19th-century hydraulic mission (i.e., the era of big hydraulic infrastructure), and these post-modern trends shaped an alternative water development discourse known as Integrated Water Resource Management (IWRM). The ideological framework of political ecology has also shaped this discourse, with minor changes and overlapping ideas [14-16].

In social sciences, "agenda setting" is a widely studied field with the aim of understanding how agendas that are set via mass media influence public policy. In communication studies, "the role in agenda setting of mass media has been documented in more than 400 social investigations for a broad range of public issues globally" [17] (p. 3). The role of media in agenda setting is highly important because different actors seek access to media to influence agenda setting. However, depending upon the nature of the public issues, their extent and method by which they are highlighted compel key stakeholders and policy decision makers to take necessary actions. Knill and Tosun [18] summarized a wide range of literature regarding agenda setting and its different types, and discussed approaches through which policy problems received attention. According to these authors, agendas can be defined as systematic, institutional or drafting, and decision agendas. In public policy formulation, policy problems receive attention via four different theoretical perspectives, as defined by Knill and Tosun [18]: the process perspective, the power distribution perspective, the institution-based perspective, and the contingency perspective. The process perspective comprises three models consisting of the outside initiative model, the mobilization model, and the inside access model. These three models explain the extent to which a certain policy problem receives attention in a policy agenda. The power distribution perspective explains how certain issues are moved onto the agenda, while others are not. This perspective describes the power distribution among the key actors involved in the public policy process, identifying those with the influence to move certain issues onto the agenda and those that do not. The institution-based perspective clarifies how institutional bias impacts agenda setting. Finally, the contingency perspective explains how agenda setting is manipulated by chance rather than by rational choice and the characteristics of politics [18]. These four perspectives explain the possible route through which different policy actors play a role in controlling the policy agenda. These policy actors can be categorized as elected public officials, judges, bureaucrats, interest groups, citizens, international organizations, and media [18]. Agenda setting of the water sector can be construed as specific sets of actions, through the abstract principles of IWRM adopted under Agenda 21 (United Nations Conference on Environment and Development, 1992) and the Dublin conference of 1992 
(International Conference on Water and the Environment, 1992). These abstract principles are defined as [19]:

(1) Fresh water is a finite and vulnerable resource, essential to sustain life, development, and the environment.

(2) Water development and management should be based on a participatory approach, involving users, planners, and policymakers at all levels.

(3) Women play a central part in the provision, management, and safeguarding of water.

(4) Water has an economic value in all its competing uses and should be recognized as an economic good.

The World Summit on Sustainable Development (2002) adopted the concept of IWRM as a global policy goal, and encouraged countries to develop IWRM and implement efficiency plans by 2005 [20]. The United Nations' Sustainable Development Goals, version 6.5, include implementation of the IWRM framework at all levels by 2030 [21,22]. This goal setting at the international level influences water policy in developing countries through international organization and provides an impulsive force for institutional reform. The process model adopted for this agenda setting is generally the "inside access model" [18], in which international organizations try to influence experts in the field and seek to place an issue on the institutional agenda.

This article attempts to scrutinize the National Water Policy (NWP) 2018 and Participatory Irrigation Management (PIM) reforms, identifying several shortcomings and promising solutions. For that purpose, the NWP is critically evaluated through a discourse analysis of the NWP text and language used to formulate the policy actions. We employ the lock-in and path dependency analytical framework to critically analyze the actions and interventions proposed in the NWP as new and "promising" solutions. Furthermore, to conclude, we develop insight from a conceptual idea of isomorphic mimicry and capability traps for the existing water institutions in Pakistan. The objective of the study is to answer the research question of whether NWP is a paradigmatic transition towards a new water narrative, namely, IWRM, as stated in the policy. The analysis helps to identify the different narratives in the water policy debate and the sensitization within the key players of the policy circle, for building a future coalition and to influence the policy action. This article is arranged as follows: first, an analytical framework for analysis is defined; second, a brief description of methods, together with the historical trajectory of irrigation practices in the Indus Basin, are presented; third, results are presented, focusing on the events and composition of the NWP, characterization of the discourse narrative and its underlying interpretation of different players, and section-wide NWP policy analysis; finally, conclusions are summarized and recommendations provided.

\section{Methods and Materials}

To understand the water reform process, the discourse analysis technique was used in this study. The discourse analysis approach identifies the storylines in the NWP through analyzing the policy texts, terms, concepts, the stylistic way of framing the policy objectives, and the context setting of policy. The works of Hastings [23] and Marston [24] were followed when analyzing key policy documents. Many analysts [25-27] have termed it the 'argumentative turn' in policy analysis to draw attention to how a particular concept or storylines frame what and who are taken into consideration, and excluded from, policy deliberation. Hajer [25] examines how particular storylines are taken up in policy through an analysis of "discourse coalitions", through which previously independent practices are actively brought together and given meaning within a common political project [25] (p. 53). These coalitions and their key actors not only seek to influence policy problems according to their views, but also to position actors in a specific way [27]. This approach, when applied to the NWP process, provided a lens to show how different key players influenced policy language and framed their positions through different water verbiages. Furthermore, the lock-in and path dependence concept were employed to understand the different sections of NWP. This approach provides insight into how different policy 
"revolutionary ideas" are limited in implementation due to historical path dependence. We observed this lock-in and path dependence in different forms, including technological, institutional, behavioral, political, economic, and infrastructure lock-in, among different policy interventions.

\subsection{Discourse Analysis}

The term discourse used in this study is borrowed from Foucault [28]. Discourse analysis is a part of the "linguistic turn" in social sciences, mainly used for the scrutiny of language and text as a framework of presuppositions and structures of thought, penetrating further than ideologic critique [29]. Ideological discourse analysis is described by Teun A. van Dijk [30] (p. 1) as "Ideological analysis of language and discourse is a widely practiced scholarly and critical endeavor in the humanities and the social sciences". Such analysis assumes that the ideology of a speaker or writer is identified by systematic analysis of language and communication. Recently, this technique has been used more often in the social sciences and has become an emerging field [31-33]. Discourse analysis is relatively open in research methods and is an interdisciplinary problem-oriented research movement with a variety of approaches, each with different theoretical models, research methods, and agendas [34].

\subsection{Lock-In and Path Dependency Concept}

Kirsi Kotilainen et al. [35] summarize the literature and differentiate the concepts of "lock-in" and "path dependence" based on different types and modus operandi. They categorize the broader classification of lock-in' into technological lock-in, institutional lock-in, behavioral lock-in, political lock-in, economic lock-in, and infrastructure lock-in. Policy studies focusing on socio-technological transitions are usually analyzed with the help of the lock-in and path dependency concepts in social sciences. The concept of lock-in is defined as "increasing returns derived from the adoption of a certain technology giving incumbent technologies an advantage over new entrants" [36]. It provides insight into how a certain technology becomes a barrier for the adoption of new technology, hence causing path dependency. In the social sciences, literature about the concept of path dependency has varied interpretations depending on the field of the research. According to Levi (1997) [37], path dependence means, "that once a country or region has started down a track, the costs of reversal are very high". Lock-in and path dependency mutually limit the adoption of socio-technological change/transition, despite the potential superiority of the new technology.

\subsection{Isomorphic/Systematic Mimicry and the Capability Trap}

Isomorphism or isomorphic mimicry is a term initially used in biology, which then began to be used in organizational sociology in the 1970s and 1980s [38]. DiMaggio and Powell (1983) [39] who "applied the concept to organizations in order to explain why so many of them look so alike in modern times, argue that the original impulse of Weberian bureaucratization-where public- and private-sector organizations became rational and bureaucratic because of competition-has long run its course". Instead of functional need, organizational change is driven by mimicry. Pritchett et al. [40] argued the existence of "capability traps", whereas Matt Andrews, during a study of public finance management reform in Africa, coined the term isomorphism to articulate his concerns about donor-assisted reform in developing countries. Financial reform in Africa introduced new formal institutions as mimicry to appease donor money. More importantly, these authors argue that these new institutions develop into a capability trap for existing institutions.

\subsection{Study Area Background and Its Historic Trajectories}

Third world countries are not familiar with the concept of a national level water policy [41]. Mexico and India are among the leading developing counties that adopted a National Water Policy during the 1980s [41]. Pakistan is a neighboring country of India, obtaining independence from British colonial rule at the same time; however, its political and constitutional evolution has been considerably slower than that of India. Decision making during the first three decades of independence was erratic 
and ambiguous. Unlike neighboring India, with multiple basins of equal status, about $75 \%$ of the territory and population of Pakistan is in the Indus Basin, although the basin was also divided during partition [42], with the headwater regulators of the eastern rivers remaining in India [43]. India and Pakistan endured transboundary water conflicts, which culminated with a temporary agreement in 1948 [43]. Formal negotiation started with the help of the World Bank, resulting in the Indus Water Treaty (IWT) of 1960. Previously, the Water and Power Development Authority (WAPDA) was established in 1958 through a presidential order [44]. The IWT gives exclusive water rights for the three eastern rivers of the Indus Basin (namely the Sutlej, Ravi, and Bias) to India, and the three western rivers in the Basin (the Indus, Jhelum, and Chenab) to Pakistan [43]. The IWT proposed Indus Basin Replacement Works (IBRW) to provide compensation and to transfer water of the western rivers to the catchment area of the eastern rivers. WAPDA carried out this project with World Bank financial and technical support. The IBRW was completed in Pakistan without any formal national level water policy.

The interstate water conflict between Pakistan and India during the early days of independence diminished the intrastate conflict between Punjab and Sindh [44]. After the IWT, the pre-partition conflict of Punjab and Sindh escalated over the distribution of water apportionment from the Indus basin. High-level judicial commissions and committees formed to settle the matter, but no successful resolution was reached [45]. This inter-provincial conflict become a point of contention in creating any formal NWP. Finally, the Water Apportionment Accord (WAA) was drafted to distribute water among the provinces. Despite its loopholes and nationalistic political criticism from upper and lower riparian zones, the WAA is the first legal water policy document for distribution of water, after the IWT. The WAA is an eight-page policy document which only discusses water distribution among the provinces and is not comparable to national water policy. After the Dublin Conference (1992), the IWRM framework began to be promoted by international financial institutions and received recognition regarding irrigation management [20]. Participatory Irrigation Management (PIM) reforms were introduced in 1997 at the pilot scale [46,47] in selected canals. This was a paradigm shift in national policy, which was again created without any formal NWP. In 2006, WAPDA attempted to formulate a national water policy, but the political turmoil of the country did not allow time and space for its approval in the political process. The current NWP is a long-awaited document in the history of Pakistan; it has been attempted several times, but not approved until April 2018.

Finally, in 2018, the NWP was approved by the Council of Common Interest (CCI) and is now in its implementation phase. Figure 1b,c compile the chronology of physical and soft interventions during the colonial, post-colonial, pre-IWT, and post-IWT periods in the Indus Basin. Physical intervention in the Indus Basin was concentrated before the IWT, specifically, before the 1947 partition. The British built a supply-driven contiguous irrigation network to help settle political unrest and to combat famine. After independence, state institutions have continued this supply-driven path and added several irrigation projects to the list, as shown in Figure 1b. Policy intervention has been concentrated in the last two decades, as shown in Figure 1c. This policy focus has been motivated through the external pressures of financial institutions and been implemented via interactions of international environmental organizations with different state departments. 


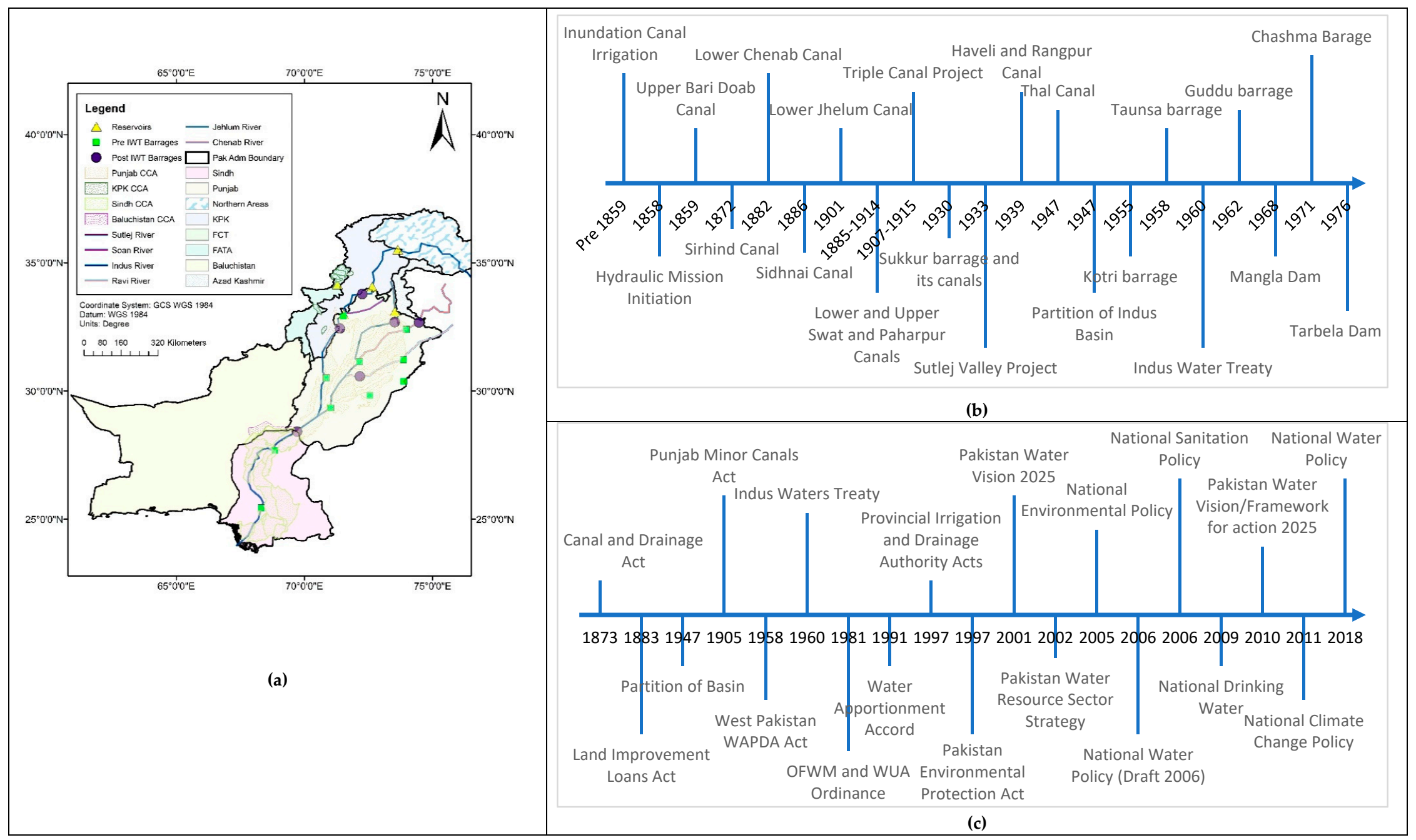

Figure 1. (a) Physical locations of major infrastructure in Pakistan; (b) chronology of physical infrastructure intervention in the Indus Basin (source [48]); and (c) chronology of soft intervention (laws and ordinances) in the Indus Basin (source [49]). 


\subsection{Materials}

To explore whether IWRM framework adoption in NWP is a policy transition, we analyzed the policy documents $(n=4)$, newspaper articles $(n=20)$, and social media communications of civil society players. We conducted semi-structured interviews $(n=41)$ with key institutional players within the water sector. For interviews, respondents were selected from different stakeholders related to water professionals $(n=10)$, academia $(n=5)$, agriculture and fisherfolk communities $(n=7)$, development professionals $(n=10)$, and irrigation engineers $(n=10)$. A total of 20 newspaper articles were selected with relevance to the water issue in 2018-2019. Newspaper articles were selected thematically, from Urdu and English media, discussing water policy from multiple perspectives, such as water scarcity, surface storage, environmental flows, mangroves and ecosystem services, and water governance. The overall document text content was analyzed through a thematically coded framework manually in an Excel sheet. Finally, we utilized the practical observation of different participants (water user groups, resource persons, guest speakers) in different seminars, conferences, and workshops discussing water policy issues. The text code identified (see in Table 1) and its underlying interpretation were used for the concrete characterization of the narrative regarding WRM and IWRM, and their interpretation by different actors or stakeholders.

\section{Results}

\subsection{Focusing Events and Composition of NWP}

Focusing events have been defined as "key events that cause members of the public as well as elite decision makers to become aware of a potential policy failure" [50]. Similar terms are used by different policy specialists for this phenomenon [51-53], for example, Cobb and Elder used the terms "circumstantial reactors" [51], "exogenous events" [52], and "causal stories" [53]. The focusing event in the context of the NWP is a research report published by the Pakistan Council of Research in Water Resources (PCRWR) that stated that Pakistan will become dry by 2025 [54]. The Supreme Court of Pakistan, an apex body of the judiciary in Pakistan, took suo moto notice over the ill planning of the government. The discourse around water scarcity was the potential driver of judicial activism and the impulse for policy formation. In addition to the action of the Supreme Court, the NWP also provides a list of international reports that play a vital role in the adoption of the new paradigm in policy discourse. These reports, which also act as a focusing event for the NWP, include:

(a) The Report of the National Commission on Agriculture, Chapters 6, 17, 18 (1988).

(b) Report of the Inter-Provincial Committee on the Apportionment of the Indus Waters (1991).

(c) Water Sector Strategy by the Asian Development Bank (2002).

(d) WAPDA's Vision 2025 Report (2003).

(e) Pakistan's Water Economy Running Dry by John Brisco (2005).

(f) Development of Integrated River Basin Management for Indus Basin: World Wildlife Fund (2012).

(g) A Productive and Water Secure Pakistan: Report by Friends of Democratic Pakistan (2012).

(h) Pakistan Vision 2025: Pillar IV: Energy, Water and Food Security; Planning Commission, Government of Pakistan (2014).

(i) A Region at Risk-the Human Dimension of Climate Change in Asia and the Pacific: Report by Asian Development Bank and Potsdam Institute for Climate Impact Research: (2017).

The NWP is a 24 page document with 29 sections excluding the preamble [55]. These sections cover a range of topics including: main water concerns in Pakistan, policy objectives, strategic priorities and planning principles, relative priority of water user, basin-level planning for development of water resources, environmental integrity of the basin, conservation of water, climate change impacts, transboundary water sharing, irrigated agriculture, rainfed agriculture, drinking water and sanitation, urban water management, hydropower, industry, groundwater, water rights/obligations, stakeholder participation, sustainable water infrastructure, water related hazards, water quality management, 
information management, public awareness, research, economic and financial sustainability, demand management, legal framework, main targets and financial requirements, and finally capacity-building of water institutions.

Planning Principle and Relative Priority of Water Uses

The planning principles are inspired and based on the IWRM concepts of equitable and efficient use, participatory decision making, access to affordable and safe drinking water as a fundamental human right, environmental sustainability, and water as a strategic resource. The priorities for the consumptive and non-consumptive uses of water shall be as follows:

(1). Drinking and sanitation (Water Sanitation and Hygiene);

(2). Irrigation, including land reclamation;

(3). Livestock, fisheries, and wildlife;

(4). Hydropower;

(5). Industry and mining;

(6). Environment, river system, wetlands, aquatic life;

(7). Forestry including social forestry;

(8). Recreation and sports;

(9). Navigation.

\subsection{Discourse Analysis of Water Policy Debate}

Discourse analysis identified two distinct policy narratives in the water policy debate of Pakistan. These policy narratives have a complete structural component as defined by Jones and McBeth [26]; in turn, these structural components have a distinct context or setting, plot, characters, and moral of the story (policy solution). The storylines identified in the water policy debate are termed the engineering narrative and the environmental narrative. This is the broader categorization of these narratives with varied and overlapping characteristics. The engineering narrative built the policy setting based on the traditional notion of water scarcity and proposed its policy solution, i.e., building new storage, to mitigate water scarcity. This narrative reorients itself through a modification in the language and text of the policy, and has an entirely different interpretation to that of the Non-Governmental Organization (NGO) and civil society activist narrative. Policy problems, such as surface storage, water demand, flooding, and infrastructure (as shown in Table 1), are interpreted entirely differently from civil society discourse. The key players or characters of this narrative are an irrigation and agriculture bureaucracy represented in vital water institutions such as WAPDA, the Planning Commission, and the Irrigation and Agriculture Departments. The environmental narrative storylines are set in the environmental and ecological damage of 19th and 20th century irrigation practices, and proposes the solution as interpreted in Table 1. The key players of this narrative are developmental professionals working with international organizations, local environmental activists, and other political nationalist groups from lower riparian areas. 
Table 1. Water Resource Management (WRM) and Integrated Water Resource Management (IWRM) narrative characterization and interpretation of thematic code by engineering and environmental narratives.

\begin{tabular}{|c|c|c|c|c|}
\hline Thematic Code & WRM Narrative & IWRM Narrative & $\begin{array}{c}\text { National Water Policy (NWP) } \\
\text { Interpretation }\end{array}$ & $\begin{array}{c}\text { NGO and Civil Society Activist } \\
\text { Interpretation }\end{array}$ \\
\hline Surface Storage & $\begin{array}{l}\text { Hydraulic mission considered } \\
\text { surface storage as an indicator } \\
\text { of economic and social progress }\end{array}$ & $\begin{array}{l}\text { Surface storage and inter-basin } \\
\text { transfer must meet ecological } \\
\text { protection standards. }\end{array}$ & $\begin{array}{l}\text { NWP sets main target to construct large } \\
\text { and medium dams and increase the } \\
\text { existing water storage capacity from } \\
\text { 14 Million Acre Feet (MAF) to } 24 \text { MAF by } \\
2030 \text { (clause } 28.4 \text { (ii)). }\end{array}$ & $\begin{array}{l}\text { Civil society circle considered surface } \\
\text { storage as waste of money. } \\
\text { Radical environmental activists even } \\
\text { demand the removal of existing } \\
\text { hydraulic structures. }\end{array}$ \\
\hline Water Demand & $\begin{array}{l}\text { Water demand met through } \\
\text { augmenting supply }\end{array}$ & $\begin{array}{l}\text { Focus is on demand } \\
\text { management; need to conserve } \\
\text { water rather than expand } \\
\text { irrigation and storage facilities. }\end{array}$ & $\begin{array}{l}\text { NWP aim to reduce the } 33 \text { percent losses } \\
\text { (Clause } 28.4 \text { (i)) occurring during the } \\
\text { conveyance and distribution of the water } \\
\text { to farms by 2030, in saline and } \\
\text { semi-saline areas. NWP focus to increase } \\
\text { water use efficiency by } 30 \text { percent } \\
\text { through the adoption of high efficiency } \\
\text { irrigation technologies and effective } \\
\text { water pricing (Clause } 28.4 \text { (iii)). }\end{array}$ & $\begin{array}{l}\text { Abandon the19th century } \\
\text { irrigation system. } \\
\text { Adopt most modern piped irrigation } \\
\text { system. The technologies are available } \\
\text { and would cost considerably less than } \\
\text { building more dams, canals, and drains. }\end{array}$ \\
\hline Flooding & $\begin{array}{l}\text { Focus is on flood control } \\
\text { through structural measures }\end{array}$ & $\begin{array}{l}\text { Focus shift from flood control to } \\
\text { flood management through } \\
\text { non-structural measures. }\end{array}$ & $\begin{array}{l}\text { NWP proposes a national flood } \\
\text { protection plan which is a mix of } \\
\text { structural and non-structural measures of } \\
\text { flood management. }\end{array}$ & $\begin{array}{l}\text { Environmental activists argued against } \\
\text { taming the natural course of the river } \\
\text { in embankments. } \\
\text { Invoke natural flood control mechanism } \\
\text { Presented the idea of the living with } \\
\text { flooding rather than controlling it. }\end{array}$ \\
\hline Infrastructure & $\begin{array}{l}\text { Focus on hard and engineering } \\
\text { infrastructure such as dams, } \\
\text { barrages, etc., for water } \\
\text { management. }\end{array}$ & $\begin{array}{l}\text { Focus is on soft infrastructure } \\
\text { such as improving allocation } \\
\text { mechanism, improving water } \\
\text { equity through model, etc., for } \\
\text { efficient water management. }\end{array}$ & $\begin{array}{l}\text { NWP proposes a mix of hard and } \\
\text { soft infrastructure. } \\
\text { Demand } 10 \% \text { Federal Public Sector } \\
\text { Development Programme budget. } \\
\text { A major portion of investment is } \\
\text { dedicated to hard infrastructure }(28.4(\mathrm{v})) \text {. }\end{array}$ & $\begin{array}{l}\text { Environmental activists are critical } \\
\text { towards the investment plan and } \\
\text { consider it as an old policy of the } \\
\text { infrastructure superiority inherited from } \\
\text { the colonial legacy. It shows the priority } \\
\text { of the irrigation bureaucracy remains } \\
\text { tilted towards the engineering solution } \\
\text { rather than soft solutions. }\end{array}$ \\
\hline $\begin{array}{l}\text { Hydropower and } \\
\text { Clean Energy }\end{array}$ & $\begin{array}{l}\text { Hydropower is considered the } \\
\text { cheapest source of energy in } \\
\text { addition to irrigation supply }\end{array}$ & $\begin{array}{l}\text { Large hydropower reservoir not } \\
\text { considered as environmentally } \\
\text { clean and economically } \\
\text { cost-effective. }\end{array}$ & $\begin{array}{l}\text { Hydraulic bureaucracy considered } \\
\text { hydropower and notion of green } \\
\text { renewable energy as an argument for } \\
\text { building hydropower dams } \\
\text { and infrastructure. }\end{array}$ & $\begin{array}{l}\text { Large hydropower reservoir not } \\
\text { considered as environmentally clean and } \\
\text { economically cost-effective. } \\
\text { Proposed solar and wind power as an } \\
\text { alternative energy source. }\end{array}$ \\
\hline
\end{tabular}


Table 1. Cont

\begin{tabular}{|c|c|c|c|c|}
\hline Thematic Code & WRM Narrative & IWRM Narrative & $\begin{array}{c}\text { National Water Policy (NWP) } \\
\text { Interpretation }\end{array}$ & $\begin{array}{l}\text { NGO and Civil Society Activist } \\
\text { Interpretation }\end{array}$ \\
\hline Capacity building & $\begin{array}{l}\text { Build capacity of human } \\
\text { resources related to engineering } \\
\text { aspects of the infrastructure. }\end{array}$ & $\begin{array}{l}\text { Build capacities for efficient } \\
\text { management of water } \\
\text { infrastructure } \\
\text { and water service provision }\end{array}$ & $\begin{array}{l}\text { NWP recognized lack of capacity in } \\
\text { IWRM implementation. } \\
\text { Capacity building of all federal and } \\
\text { provincial water institutions given } \\
\text { high priority. }\end{array}$ & $\begin{array}{l}\text { There is a need to build capacity of the } \\
\text { institutions multidimensionally, as water } \\
\text { is a multidimensional subject. }\end{array}$ \\
\hline Institutional reforms & $\begin{array}{c}\text { Introduced a typical hydraulic } \\
\text { bureaucracy and considered it } \\
\text { as a custodian of water and } \\
\text { infrastructure. }\end{array}$ & $\begin{array}{l}\text { Create representative and } \\
\text { participatory institutions at } \\
\text { project or watershed levels. }\end{array}$ & $\begin{array}{l}\text { NWP considered the participatory } \\
\text { decision making at federal and provincial } \\
\text { level as a planning principle. } \\
\text { NWP considered farmers as stakeholders } \\
\text { in irrigation management and their } \\
\text { participation is encouraged. }\end{array}$ & $\begin{array}{c}\text { Support decentralization of power and } \\
\text { promote stakeholder participation in } \\
\text { decision making. }\end{array}$ \\
\hline Policy and legal regime & $\begin{array}{l}\text { There is no concept of } \\
\text { basin-level water policy and } \\
\text { laws. Generally, laws were } \\
\text { introduced related to irrigation } \\
\text { and drainage for smooth } \\
\text { governance of the system. }\end{array}$ & $\begin{array}{l}\text { Introduce policy and legal } \\
\text { regime for a transition to } \\
\text { basin-level water governance. }\end{array}$ & $\begin{array}{l}\text { NWP recognized as an effective } \\
\text { institutional support, with a legal cover } \\
\text { for the implementation of the policy. } \\
\text { A national water council is proposed at } \\
\text { federal level and "provincial water } \\
\text { authorities" at provincial level. }\end{array}$ & N/A \\
\hline Investment priority & $\begin{array}{l}\text { Water infrastructure considered } \\
\text { as new temples of development. } \\
\text { Investment priority is creating } \\
\text { new storage, irrigation schemes, } \\
\text { and inter-basin water } \\
\text { transfer projects. }\end{array}$ & $\begin{array}{l}\text { Invest in infrastructure } \\
\text { modernization for } \\
\text { improved service } \\
\text { delivery and water } \\
\text { use efficiency. }\end{array}$ & $\begin{array}{l}\text { NWP propose augmentation of surface } \\
\text { storage as number one } \\
\text { investment priority. }\end{array}$ & $\begin{array}{l}\text { Invest in modernizing irrigation practice } \\
\text { through modernized technology. }\end{array}$ \\
\hline $\begin{array}{l}\text { Managing ecosystem } \\
\text { impacts }\end{array}$ & $\begin{array}{l}\text { There is no concern for } \\
\text { ecosystem management. }\end{array}$ & $\begin{array}{l}\text { Proactive management of water } \\
\text { quality and ecosystem impacts } \\
\text { at project level; invest in } \\
\text { low-cost recycling. }\end{array}$ & $\begin{array}{l}\text { NWP accepted the Environmental Flows } \\
\text { in the policy objectives as one of the main } \\
\text { concerns. Surface storage presented as } \\
\text { mediation to ensure EFs. EFs quantified } \\
\text { as } 5000 \text { cusecs daily. }\end{array}$ & $\begin{array}{l}\text { Environmental activist demand } 30 \mathrm{MAF} \\
\text { annually to combat sea intrusion. } \\
\text { Radical activists associated with fisheries } \\
\text { community, pleading the "keep the river } \\
\text { free" from damming and opposing } \\
\text { surface storage. }\end{array}$ \\
\hline $\begin{array}{l}\text { Water as social and } \\
\text { economic good }\end{array}$ & $\begin{array}{l}\text { Water resource engineering. } \\
\text { Agriculture expansion. } \\
\text { No concept of pricing; focus is } \\
\text { on subsidies for bulk user. }\end{array}$ & $\begin{array}{l}\text { Volumetric water pricing for } \\
\text { bulk users; } \\
\text { partial cost recovery for retail } \\
\text { consumers; targeted subsidies } \\
\text { for the poor }\end{array}$ & $\begin{array}{c}\text { NWP frames the low water charges in } \\
\text { agriculture sector as a policy concern. } \\
\text { There is a clear intention to revise the } \\
\text { pricing mechanism. }\end{array}$ & $\begin{array}{c}\text { Consider water as economic good and } \\
\text { does support subsidies for any } \\
\text { commercial activity. } \\
\text { Consider safe drinking water as a basic } \\
\text { human right. }\end{array}$ \\
\hline
\end{tabular}


Unfortunately, the NWP does not have a shared understanding of the policy problem and solution. The storylines to construct the problem and the proposed solution differ between the hydraulic bureaucracy and civil society activists. These are severe differences in the explicit versions of reality promoted during the policy implementation process. This discursive divide prevailed over the announcement of the construction of the Diamer Basha Dam. The hydraulic bureaucracy tries to muddle the paradigmatic shift of IWRM with existing or old practices. Thus, the moral of the story (policy solution) in the policy remains muddled with varied interpretations. For example, water scarcity storylines are interpreted differently in the two narratives. The engineering narrative interprets water scarcity as a necessary outcome of the lack of new storage construction during the past four decades, whereas the environmental narrative interprets water scarcity as a result of the continuation of 19th century irrigation practices and failure to adopt new technologies. The proposed solution in the NWP can be best understood from the context and preamble paragraphs of the policy document. This section sets the context for policy measures. This context-setting orients the reader to take a specific view of the NWP, i.e., water scarcity is due to the failure to construct dams during the past four decades. The engineering perspective adopts the IWRM framework tactically, like a compulsion to remain ideologically correct. Table 1 illustrates the thematic understanding of the different themes used in the policy document.

\subsection{Thematic Analysis of NWP Policy Solution}

\subsubsection{Paradigm Policy Shift/Transition}

It would appear that the NWP instigated a paradigm shift from the Water Resource Management (WRM) to the Integrated Water Resource Management (IWRM) discourse. Historically, the WRM narrative remained dominant in policy decisions related to water issues. The hydraulic bureaucracy perpetuated the WRM narrative with large-scale infrastructure (such as dams, barrages, flood embankments, and drainage network construction) as a solution to water challenges. The period of the 19th and 20th centuries encompasses the timeframe of major state-led infrastructure development, as it was the era of state formation and deconstruction of colonial rule. The neoliberal model of the economy gave an impetus to the IWRM framework and began criticizing state-led water infrastructure development. Development was rejected for numerous reasons: because it is the 'new religion of the West' [56], it is the imposition of science as power [57], it does not work [58], it means cultural Westernization and homogenization [59], and it brings environmental destruction [60]. It was rejected not merely on account of its results but because of its intentions, its worldview, and mindset. The hydraulic mission of the 19th century came under a wide array of scrutiny in developed countries because the available feasible space was limited for new supply-side infrastructure [8]. The NWP accepted the IWRM framework with an entirely different interpretation of the concept compared to various environmental activists and organizations. Water scarcity is a typical discourse used by the hydraulic bureaucracy as a persuasive tool to propose large-scale irrigation infrastructure [61]. The preamble of the NWP is inspired by the water scarcity discourse of the old hydraulic bureaucracy, but then proposes the IWRM strategy for implementation. The NWP proposes many demand-side managements measures, in addition to highlighting the negligence in not pursuing large water storage infrastructure over the last four decades.

\subsubsection{Integrated Basin-Level Planning and River Basin Organization}

The NWP proposes integrated basin-level planning, while IWRM proposes global planning, defining a basin as the hydrological unit for any location. NWP describes it in Clause 5.1:

"The principles of integrated and unified planning, development and management shall be adopted. Water demand shall be estimated for all sectors, within the Basin and outside the Basin. The process of holistic approach to planning shall aim at accommodating a fair and stable economic and social development within an integrated drainage basin management. 
Environmental impact assessment studies shall be carried out concurrently with project feasibility studies for selecting project scope and layout, consistent with productivity, economic viability, social acceptability and environmental sustainability."

This basin-level planning is promising, but unfortunately the NWP overlooks practicality dimensions. In addition to being transboundary, the Indus Basin is also an inter-provincial basin, with different political and administrative mandates. The NWP advocates basin-level planning but no basin development plan has been proposed, and there is nothing in the pipeline. Basin-level planning was proposed when the NWP draft committee clearly became aware that water is a provincial subject, as indicated in the 1973 Constitution. Interestingly, the provincial chief minister signed this document, thus accepting the basin as a unit of planning, being fully aware that water is a provincial subject. In addition, provinces have already contested claims regarding water theft in allocation [62]. The Indus River System Authority (IRSA), a river basin organization, has been unable to provide an acceptable resolution regarding equitable water allocation and transparent data monitoring for all parties during the past 30 years [63]. Under such circumstances, the idea and wish of basin-level planning is practically ambitious. In addition to these context-specific issues, there is a fundamental question regarding the IWRM, namely, are there any successful examples of the past 30 years showing planning of a single basin in an "integrated" manner globally [64]? The term "integrated" itself requires further elaboration on how the integration is being assessed.

\subsubsection{Environmental Integrity of Basin}

Environmental flow is a hotly debated topic within policy circles and among different stakeholders, both globally and locally [65]. Naturally, excess water in the annual cycle flows to the lower delta of major river basins after limited use in the upper riparian zone. The limited water uses and control over the natural river flow in the upper riparian zone have not initiated any serious water dispute among the co-riparian residents of the basin. Following the 19th century construction of engineering infrastructure, which provided leverage to the upper riparian zone (see Figure 1), thus disrupting the natural course of the river, the socio-hydrology of the Indus Basin became complicated and conflicts among riparian groups emerged. The discussion of environmental flow (EF) below Kotri-the site of the lowest regulating infrastructure on the Indus River before it drains into the Arabian Sea-is an unfinished agenda topic of the WAA of 1991. It was decided that a research study would be carried out to estimate the environmental flows below Kotri. WAPDA hired an international consultant and compiled the report, but the findings of these studies were controversial due to a lack of transparency in data management and a political trust deficit among the federating units [66]. The NWP again reflects concerns regarding the EF requirement below Kotri to mitigate sea intrusion. NWP Clauses 6.3 and 20.5.2 reflect these concerns as follows:

"Environmental flows shall be ensured in the rivers to maintain a sound environment for the conservation of the river ecology, morphology, delta and coastal ecosystem and fisheries"

(Clause 6.3)

"Based on new realities of seawater intrusion and to conserve aquatic ecosystem, required environmental flows will be reassessed and assured so as to address the issues on long term basis"

(Clause 20.5.2)

This is a longstanding issue that haunts the hydro-social solidarity of the federating state/provinces and which requires a fair resolution, as promised. Previously, WAPDA calculations of EFs were considerably less than the estimates of international environmental organizations such as International Union for Conservation of Nature (IUCN) and World Wide Fund for Nature (WWF) [67]. The mechanism to commission studies for the estimation of EFs must represent the upper and lower riparian academic 
institutions. Furthermore, study models and their data must produce replicable findings to ensure the transparency and political legitimacy of the study. This should be the second-most important priority, after drinking water quality and sanitation, because, without this step, basin-level planning is not feasible. To the contrary, in its ranking of water use priorities, the NWP lists the environment and aquatic life at number six.

\subsubsection{Water Pricing}

The NWP intended to revise water pricing as a leverage tool to enhance water use efficiency. However, the method of assessment of economic value for different sectors and uses is not specified in the document. Dinar and Subramanian (1996) [68] surveyed the water pricing mechanisms of 22 countries and discussed the multiple factors, such as water availability index, gross national product, and budget deficits, that push countries to reform their pricing mechanisms. Pakistan has high water stress and faces a substantial budget deficit; nonetheless, no progress toward reforming water prices in agriculture has been made. In Pakistan, the agriculture sector is the primary user of water (accounting for more than $90 \%$ of total consumption) and contributes almost 19\% of GDP [69,70]. Water pricing in agriculture is based on volumetric measurement of water delivered or land under cultivation. Previously, different approaches have been practiced, such as crop-based and land-based assessment, without any significant success. In Pakistan, as well as in many developing countries, many different reasons exist for low water fee collection rates, including the following:

- No link between fees collected and funds allocated to an irrigation project.

- $\quad$ Lack of farmer participation in project planning and management.

- Poor communication and lack of transparency between farmers and irrigation management.

- Poor water delivery service (timing, duration, or quantity inadequate).

- Low priority given to fee collection, efficient water use, and system Operation \& Maintenance.

- Small size and meager incomes of irrigated farms.

A report published by the Planning Commission [71] revealed irrigation networks only meet $20 \%$ of their operation and maintenance costs annually. Such a low recovery for existing water charges (86 Rs/acre) was found to be due to weak institutional performance. Irrigation reform, introduced as a farmer-managed irrigation system, also failed to achieve $100 \%$ recovery of water charges. The institutional lock-in (capacity of an institution to reform itself to achieve an entirely different goal, as opposed to routine functioning) is a significant constraint for any tangible progress in the collection of water charges. Revision of water charges also represents a highly unpopular decision for any political government, with fears of voter retribution. In Pakistan, 53\% of the population is linked to the agriculture sector and is politically represented through its landed elite, who would never support any legislation that barred them from agricultural income tax. Since the NWP was approved in 2018, no apparent effort or planning has been made in the direction of water price reform.

\subsubsection{Dichotomy of Demand Side and Supply Side Management}

The NWP proposes demand-side management (DSM) as a policy objective, along with some tangible targets. IWRM overwhelmingly focuses on DSM for water scarcity rather than enhancing the supply side. The NWP points out a 33\% reduction in inflows due to losses during conveyance and distribution, and a 30\% increase in efficiency through efficient field application (see Clauses 28.3 and 28.4). To reduce conveyance losses, a substantial drive is proposed for water course lining (see Clause 3.1), whereas a $30 \%$ gain in efficiency is predicted through the adoption of High Efficiency Irrigation Systems (HEIS) (see Clauses 10.3 and 7.4), realistic water pricing (see Clause 28.4), replacement and refurbishment of decades-old irrigation infrastructure (see Clause 28.5), public awareness for water conservation (see Section 23), crop zoning (see Clause 5.6.7), and sustainable groundwater management (see Section 16). 
Previous experience of donor-funded projects to motivate the adoption of HEIS in the field remains very low. The World Bank funded a program called the Sindh Irrigated Agriculture Productivity Enhancement Program (SIAPEP) to implement HEIS on 35,000 acres with $60 \%$ subsidies [72]. During the past three years, the Sindhi government only succeeded to utilize 900 acres, representing only $2.5 \%$ of the target [72]. Technological and behavioral lock-in are a barrier to large-scale adoption of HEIS. Practicing surface flood irrigation or HEIS is not only the choice for optimal option selection. Network effects or network externalities, such as the absence of a localized service provider, also exacerbates this socio-technical and behavioral lock-in and path dependency for surface irrigation. This historical path dependency is a supply-driven contiguous irrigation network, irrigating 22.50 million hectares of land in different canal command areas. The transition of such a colossal irrigation network towards a demand-driven model is no small task, and involves a substantial financial cost. From scrutiny of the different policy measures proposed in the NWP related to core infrastructure investment, then it is evident that the supply-side infrastructure investment discourse dominates. This is reflected in the main concerns discussed in the section "Indus Basin Replacement Works" dams (in particular) are approaching the end of their designed life span due to siltation, and replacement storage is thus required (see main section concerns, Clause V). It is also evident from the investment priority plan, as proposed in Section 28 : almost $68 \%$ of the total investment plan is dedicated to hard infrastructure (i.e., new storage, dams, dykes, flood embankments, etc.).

\subsubsection{Participatory Irrigation Management Reforms}

The hydraulic bureaucracy has been challenged for multiple reasons globally, including, but not limited to, internal rifts of bureaucracy, financial cuts after structural adjustment programs, environmental movements, decentralization, and rising civil society [73]. The purpose of the experiment of state and civil society cooperation introduced in the irrigation sector to enhance stakeholder participation is to improve the water governance in irrigation systems and share the financial burden of O\&M costs [74]. This participatory reform package was introduced in the Indus Basin Irrigation System (IBIS) on selected canal command areas in parallel with the traditional working of the provincial irrigation departments. Provincial Irrigation and Drainage Authorities (PIDAs) were established in 1997 and management of selected canal commands was transferred to newly established farmer organizations (FOs).

Pakistan faced economic crises due to the ban on international trade after the military coup of the civilian government. Military regimes implemented participatory irrigation management reform to appease international donor agencies. This was the first intrusion of the IWRM participatory framework in the name of the democratization of the irrigation governance, and a step towards transparency and the efficient use of water resources through stakeholder consultation. The participatory reform model and framework was imported from Mexico and implemented after refurbishing it with localized terminology.

Thereafter, a large amount of literature was produced regarding the working environment of these reforms and their impact on the irrigation system performance [75-80]. After the "Dublin principles", there was more emphasis on stakeholder participation and recognition of the farming community as stakeholders in irrigation system management. Since the 1990s, the notion of good governance has dominated the ideological space in state-building approaches and international financial institutions. An idealized toolkit of PIM principles and practices are being presented as an ultimate caveat to state institutions and to enable states to enact development. Aid-dependent countries have accordingly produced a range of "good" institutions with the "right" types of policy and institutional architecture in place, in response to the incentives of aid conditioned to produce this effect [81,82].

The evidence suggests that an attempt to transplant best practices from one context to another has weakened the already existing institutional functioning [81,83]. Researchers [83] argue that states become stuck in capability traps where they cannot perform what is expected of them, or what they promised to do in the policy frameworks that they designed in response to international pressures. 
They may have policies that are classified as good but cannot implement them. The World Bank evaluated the PIM reforms in Punjab [77] and reported that water theft increased in distribution systems managed by farmer organizations compared to bureaucratically controlled irrigation systems. This study also revealed that water theft is greater along canals where land inequity is a more prevalent issue, with big landowners situated at the head of the channel. Recently, Ward et al. [84] studied the impact of informal institutions on the performance of the formal institution in Sindh, and found that kinship power asymmetry has a significant impact on collective action and irrigation management performance. Ward et al. [84] studied participatory irrigation management reforms in Sindh, Pakistan. They studied the 22 farmer organizations in the Left Bank Area Water Board (LBAWB) and found that only $10 \%$ of the study respondents received formal training from Sindh Irrigation and Drainage Authority (SIDA). Based on personal field survey observation during empirical data collection about the functioning of the farmers' organization in Sindh, the authors draw on an argument on the broader discourse of PIM reforms, that a considerable gap exists between theory and practice. Externally conceived ideas of farmer organizations, based on the doctrine of Integrated Water Resource Management (IWRM), are in practice mostly dysfunctional.

Based on key informant interviews undertaken for the present study, we conclude that PIM reform is a typical example of the capability trap for existing irrigation institutions, and its adoption is an isomorphic mimicry to appease international donors. The noble idea of implementing universal norms for governance per IWRM principles is problematic because it ignores institutional and technological path dependency issues, as well as the socio-cultural context of a region. Community needs and collective efficacy are very much interrelated with the adoption of any governance framework. More importantly, reforms are invariably difficult when there is no evolutionary urge persisting among the existing institution. This is why these reforms were reversed in the Punjab province, Pakistan, where they were first initiated in 1997. If the trend of misreading community needs and collective efficacy continues, future water development will become unsatisfactory for water system users.

\subsubsection{Information Management}

Punjab and Sindh provinces of Pakistan, being upper and lower riparian, respectively, have traditionally accused each other of misreporting and maneuvering river flow data reported at key regulating structures, where water flows from Punjab to Sindh $[85,86]$. This is a typical finger-pointing approach due to the lack of transparent data collection and information management mechanisms. Sindh and Punjab provinces have been locked in a state of mutual accusation regarding water since prior to the partition of 1947 [45]. The reliability of water measurements has caused much controversy at multiple scales [44]. A detailed plan for information management is discussed in Section 22 of the NWP. Information management is an essential pre-requisite of any informed decision making; unfortunately, Pakistan has faced challenges in this regard since its inception in 1947. A lack of basic level water accounting data creates mistrust among the federating provinces and states, which thereby continuously jeopardizes basin-level planning. Telemetry systems for discharge measurements were installed by WAPDA in 2002 and handed over to IRSA to manage. However, IRSA abandoned their use after just a few months because the systems are not fully automatic. Moreover, the subjective choice of some coefficients in the discharge volume calculation formula greatly diminished the usefulness of the telemetry systems [44].

Another example of telemetry implementation is at the canal level for equitable distribution of water at the head and tail of the canal. The World Bank provided funding and installed a telemetry system in the NARA canal, Sindh, in 2008. The fate of this canal-level telemetry system was similar to that of IRSA. The behavior and institutional lock-in of institutions, such as IRSA and the Provincial Irrigation Departments, played a greater role in the failure to successfully implement the systems. The NWP, unfortunately, does not provide a situational analysis of past intervention failures, nor an assessment of why future interventions might produce different outcomes. 


\subsubsection{Revitalizing and Restructuring of WAPDA and Irrigation Departments}

NWP policy proposed the restructuring of WAPDA and other institutions such as Irrigation Departments. For successful implementation of any policy, capacity building of the institutions is necessary. Here the fundamental questions relate to the type of revitalizing and restructuring that are required, and how these fit into the policy objective and implementation intention. WAPDA and Provincial Irrigation Department (PID's) have historically been dominated by civil engineers, limiting these institutions to produce only engineering solutions. Moreover, civil engineers receive training in the design and construction of infrastructure, rather than in water management. Civil engineers see their job as looking after the infrastructure, that is, diversion weirs, canals, linings, desilting, drop structures, stilling basins, and siphons. They do not see themselves as stewards of the natural resource of water. They do not account for how much water they divert from the natural environment and how much is used/needed by crops. The professional diversity of these institutions is paramount for any tangible results and to help remove the institutional lock-in of these institutions.

\subsubsection{Policy Research}

The professional capacity of policymaking institutions is minimal. Again, these institutions are dominated by professional civil engineers who have less exposure to public policy. In contrast, the backgrounds of the staff of public policy institutions are predominantly grounded in social sciences, and are less grounded in the technical aspects of water. The crossroads of these two fields is crucial for any evidence-based policymaking. Water experts and academic researchers are neglecting to convey science-based evidence into policy circles, and public policy professionals lack the understanding of the technical jargon of the academic research.

Policy actions must emerge based on sound policy research and multidimensional analyses of the proposed policy action. However, it seems that NWP 2018 is full of such policy statements-such as the main target of Section 28-which are not based on scientific research and lack a meaningful direction.; for example, "Increase of at least 30 per cent in the efficiency of water use by producing 'more crops per drop'. This will require the use of new technologies like drip and sprinkler irrigation and more realistic water pricing policy" (see Clause 28.4.3). The policy research excludes consideration of key factors, such as the extent to which an increase in the current water prices is realistic.

Furthermore, what is the willingness of farmers to pay? Another obvious example is Clause 28.4.4: "Gradual replacement and refurbishing of decades-old irrigation infrastructure following an adequate asset management plan". The NWP demands 30 billion rupees for research by 2030 (see Clause 28.11). There is a need to avoid wasting public money on superfluous and irrelevant research projects. This research endowment should focus on projects that help to establish research databases and develop data analytics tools, in order to organize data for meaningful policy inference, analyze current and future developmental needs, and develop a transparent decision-making tool for future financial investment prioritization. To overcome the technical and policy gap, there is a need to invest in a designated water policy research center. The role of this research center would be to bridge the technical and policy professional gap and coordinate the national research agenda for 2030.

\subsection{Isomorphic Mimicry and Capability Trap}

Dinar [87] studied institutional water reform in six different countries and summarized exogenous and endogenous factors, and their interrelated linkages, in the policy change process. It was found there is a difference of opinion on the contribution of exogenous factors to the policy transition. Some argue that these cosmetic changes under international commitments help create a "pro-reform atmosphere" for any substantive change [87]. On the other hand, policy analysts consider this isomorphic mimicry a capability trap for existing institution. They argue that creating a plethora of institutions provides an escape from responsibilities and facilitates blame games among those institutions. Thus, the global agenda setting of water in the shape of the IWRM framework and its donor-driven mimicry adoption 
has raised some pertinent concerns among water experts. Hassing et al., as cited in [20], reported the finding from a large survey that three-quarters of countries adopting IWRM terminology did so just to mimic donor agencies. This is because donors are more concerned that the language of IWRM appears in formal and legal documents as an indicator of adoption, rather than about solving actual water problems. A global survey carried out by the Global Water Partnership (2006) [88], UN-Water (2008) [89], and United Nations Environment Programme (2012) [90], asked respondents to attribute changes in policy rather than the impact of the policy. In the case of the NWP, water and agriculture policy experts implicitly or explicitly assume that adoption of IWRM language is sufficient to solve the water problem. This is because supporting agencies, such as the Asian Development Bank (ADB), promote these concepts as conditions of aid and loans [20]. The ADP policy, Water for All, encourages loan recipient countries to pursue river basin organization, decentralization of decision making, transfer of water rights, cost recovery and pricing, and participatory irrigation management as a pre-requisite for any water sector funding. Under these loan conditions, Pakistan introduced participatory reform in the irrigation sector and created another parallel institution, that is, the PIDAs. However, the experience of this institutional reform of irrigation systems has been unable to create a pro-reform atmosphere even after two decades. In different canal command areas, irrigation infrastructure continues to suffer, with both institutions (i.e., PIDs and PIDAs) blaming each other for this poor performance. In addition to the reversal of PIM reform in Punjab, the NWP continues to embody participatory irrigation management notions. These preconditions for funding overlook water priorities by diverting attention from the actual water problem and its solution. Under these conditions, countries in Asia and Africa have repackaged existing water activities as IWRM and halted any alternative thinking.

\section{Conclusion and Recommendations}

\subsection{Conclusions}

Findings of this comprehensive analysis of the water policy debate through examination of the NWP policy text and interviews with key players can be summarized with the following key messages:

(1) The overall analysis revealed that the engineering narrative is dominant in policy circles and uses the notion of large-scale infrastructure construction as an exceptional measure to overcome the current loss of storage potential due to sedimentation. In addition, the adoption of the IWRM framework indicates that state institutions desire to imbue water policy reform with international credibility.

(2) The key players associated with the supply-driven path of the water sector-in the shape of hydraulic bureaucracies, federal and provincial politicians, and irrigators-are dominant in the policy process compared to environmental interest groups. Interestingly, the engineering interest group has less ability to mobilize and act collectively than the environmental interest group.

(3) Global agenda setting ignores the local context in goal setting, leading to institutional mimicry in developing countries, and consequently becoming a capability trap for existing institutions.

(4) Infrastructure, technological, and behavioral path dependency of contiguous irrigation networks limits the transition to highly modernized irrigation practices.

(5) Institutional reforms introduced in the form of PIM for stakeholder participation in decision making resulted in institutional rivalry (lock-in) and backfired due to numerous social and political reasons.

(6) Water policy lacks monitoring assessment indicators during the implementation phase and does not provide a policy rubric for deciding priority targets and how water resource sustainability can be improved. In the absence of such a rubric, the policy is unable to distinguish the actions that work from those that do not. The NWP displays a lack of policy research and thus does not provide a clear policy direction.

(7) The NWP has several policy objectives that are too broad; the implementation targets defined only address a limited number of policy objectives and concerns. 


\subsection{Recommendations}

The NWP discloses the lack of a transparent water accounting system in the basin; without such information, future planning and allocation is near impossible. Moreover, under such conditions, it is unlikely to achieve the targets of environmental protection and efficiency. Until the serious gaps relating to information, policy research and monitoring, and decision assessment indicators are addressed, the NWP will remain a feel-good document based on high moral standards but without any practicability. The following is a set of prerequisite recommendations for an effective water policy:

(1) There is a need to choose a clear approach from a management or ideological approach.

(2) There is a need to define the main concerns and a clear quantitative rationale (no need to include everything in the list).

(3) There is a need to establish a policy research center with a clear mandate to formulate consensus science- and evidence-based policy actions through consultative and participatory approaches.

(4) National research agendas should be consistent with the main policy concerns and expressed as a qualitative statement with a quantitative assessment.

(5) The quantitative statement should be defined in the policy objective with anchoring actions.

(6) A policy research center should help to devise a monitoring and evaluation tool to track progress on policy goals and objectives.

(7) The existing functions of key departments, including PIDs and WAPDA, should be restructured and reformed via a transition from an engineering-only solution to a water resources, engineering, and management approach through the induction of experts of diverse backgrounds and the development of cross-sectional/inter-organizational coordination. The monolithic structure of the human resources of these institutions limits their working efficacy; thus, these departments must be diverse professionally.

Author Contributions: Conceptualization, M.A.; Formal analysis, M.A., K.A., D.H. and S.J.; Funding acquisition, S.J.; Investigation, K.A.; Methodology, M.A., A.U., D.H. and A.A.S.; Supervision, K.A., A.U. and A.A.S.; Visualization, D.H.; Writing—original draft, M.A.; Writing—review \& editing, M.A., K.A., A.U., A.A.S. and S.J. All authors have read and agreed to the published version of the manuscript.

Funding: This research was carried out with Support from the Strategic Priority Research Program of the Chinese Academy of Sciences (XDA 20010201).

Acknowledgments: We are thankful to the two anonymous reviewers and guest editor of the special issue Jale Tosun for constructive comments and suggestions. We are also thankful to Mercedes Ward and Jewell Lund from the University of Utah, USA for their valuable feedback and Zafar Hussain from the Planning Commission for providing relevant literature of the NWP. This research was carried out by the support of USPCASW and from the Strategic Priority Research Program of the Chinese Academy of Sciences (XDA 20010201).

Conflicts of Interest: The authors declare no conflict of interest.

\section{References}

1. Cambridge Dictionary, Internet Access. Available online: https:/dictionary.cambridge.org/dictionary/ english/policy (accessed on 24 March 2020).

2. Van der Zaag, P.; Savenije, H.G. Principles of Integrated Water Resources Management; Unesco-IHE: Delft, The Netherlands, 2004.

3. Lichtheim, G. Marx and the 'Asiatic Mode of Production'. Karl Marx's Soc. Political Thought 1963, 6, 35-58.

4. Walsh, M.T. Against Consensus? Anthropological Critique and the Deconstruction of International Water Policy. Social Anthropol. 2004, 11, 18-19.

5. Agnihotri, I. Ecology, land use and colonization: The canal colonies of Punjab. Indian Econ. Soc. Hist. Rev. 1996, 33, 37-58. [CrossRef]

6. Weil, B. The rivers come: Colonial flood control and knowledge systems in the Indus Basin, 1840s-1930s. Environ. Hist. 2006, 12, 3-29. [CrossRef]

7. Evers, H.D.; Benedikter, S. Hydraulic bureaucracy in a modern hydraulic society strategic group formation in the Mekong delta, Vietnam. Water Altern. 2009, 2, 416-439. 
8. Crow-Miller, B.; Webber, M.; Molle, F. The (Re)turn to infrastructure for water management? Water Altern. 2017, 10, 195-207.

9. McCulligh, C.; Tetreault, D. Water management in Mexico from concrete-heavy persistence to community-based resistance. Water Altern. 2017, 10, 341-369.

10. Price, D.H. Wittfogel's neglected hydraulic/hydro agricultural distinction. J. Anthropol. Res. 1994, 50, 187-204. [CrossRef]

11. Disco, C. Remaking "nature": The ecological turn in Dutch water management. Sci. Technol. Hum. Values 2002, 27, 206-235. [CrossRef]

12. Castree, N. Neoliberalism and the biophysical environment 2: Theorizing the neoliberalisation of nature. Geogr. Compass 2010, 4, 1734-1746. [CrossRef]

13. Castree, N. Neoliberalism and the biophysical environment: A synthesis and evaluation of the research. Environ. Soc. 2010, 1, 5-45. [CrossRef]

14. Pieterse, J.N. The cultural turn in development: Questions of power. Eur. J. Dev. Res. 1995, 7, 176-192. [CrossRef]

15. Molle, F.; Mollinga, P.P.; Wester, P. Hydraulic bureaucracies and the hydraulic mission: Flows of water, flows of power. Water Altern. 2009, 2, 328-349.

16. Mollinga, P.P.; Veldwisch, G.J. Ruling by canal: Governance and system-level design characteristics of large-scale irrigation infrastructure in India and Uzbekistan. Water Altern. 2016, 9, 222-249.

17. McCombs, M.; Valenzuela, S. The agenda-setting theory. Cuadernos Inf. 2007, 20, 44-50. [CrossRef]

18. Knill, C.; Tosun, J. Public Policy: A New Introduction, 2nd ed.; Macmillan International Higher Education: London, UK, 2020.

19. Harmancioglu, N.B. Overview of water policy developments: Pre-and post-2015 development agenda. Water Resour. Manag. 2017, 31, 3001-3021. [CrossRef]

20. Giordano, M.; Shah, T. From IWRM back to integrated water resources management. Int. J. Water Resour. Dev. 2014, 30, 364-376. [CrossRef]

21. UN SDGs. Transforming Our World: The 2030 Agenda for Sustainable Development. Resolution Adopted by the UN General Assembly. 25 September 2015. Available online: https://sustainabledevelopment.un.org/ post2015/transformingourworld (accessed on 22 June 2016).

22. Breuer, A.; Oswald Spring, U. The 2030 Agenda as Agenda Setting Event for Water Governance? Evidence from the Cuautla River Basin in Morelos and Mexico. Water 2020, 12, 314. [CrossRef]

23. Hastings, A. Connecting linguistic structures and social practices: A discursive approach to social policy analysis. J. Soc. Policy 1998, 27, 191-211. [CrossRef]

24. Marston, G. Metaphor, morality and myth: A critical discourse analysis of public housing policy in Queensland. Crit. Soc. Policy 2000, 20, 349-373. [CrossRef]

25. Hajer, M. The Politics of Environmental Discourse: Ecological Modernization and Policy Process. Soc. Forces $1997,75,1138$.

26. Jones, M.D.; Mcbeth, M.K. A Narrative Policy Framework: Clear enough to be Wrong? Policy Stud. J. 2010, 38, 329-353. [CrossRef]

27. Asthana, V. The urban water reform project: A critical discourse analysis of the water policy making process in Delhi. Hydrol. Res. 2011, 13, 769-781.

28. Graham, L.J. Discourse Analysis and the Critical Use of Foucault. 2005. Available online: http://eprints.qut.edu. au/2689 (accessed on 12 January 2020).

29. Pálsson, G. The Textual Life of Savants: Ethnography, Iceland, and the Linguistic Turn; Psychology Press: East Sussex, UK, 1995.

30. Van Dijk, T.A. Handbook of discourse analysis. In Discourse and Dialogue; Wiley: Hoboken, NJ, USA, 1985.

31. Mehta, L. The Politics and Poetics of Water: The Naturalization of Scarcity in Western India; Orient Blackswan: Hyderabad, India, 2005.

32. Hussein, H. Lifting the veil: Unpacking the Discourse of water scarcity in Jordan. Environ. Sci. Policy 2018, 89, 385-392. [CrossRef]

33. Daus, M.; Koberger, K.; Gnutzmann, N.; Hertrich, T.; Glaser, R. Transferring Water While Transforming Landscape: New Societal Implications, Perceptions and Challenges of Management in the Reservoir System Franconian Lake District. Water 2019, 11, 2469. [CrossRef] 
34. Fairclough, N.; Wodak, R. Critical discourse analysis. Discourse Stud. Multidiscip. Introd. 1997, 2, $258-284$.

35. Kotilainen, K.; Aalto, P.; Valta, J.; Rautiainen, A.; Kojo, M.; Sovacool, B.K. From path dependence to policy mixes for Nordic electric mobility: Lessons for accelerating future transport transitions. Policy Sci. 2019, 52, 573-600. [CrossRef]

36. Arthur, W.B. Increasing Returns and Path Dependence in the Economy; University of Michigan Press: Ann Arbor, MI, USA, 1994.

37. Levi, M. A model, a method, and a map: Rational choice in comparative and historical analysis. Comp. Politics 1997, 28, 78 .

38. Deephouse, D.L. Does isomorphism legitimate? Acad. Manag. J. 1996, 39, 1024-1039. [CrossRef]

39. DiMaggio, P.J.; Powell, W.W. The iron cage revisited: Institutional isomorphism and collective rationality in organizational fields. Am. Sociol. Rev. 1983, 48, 147-160. [CrossRef]

40. Pritchett, L.; Woolcock, M.; Andrews, M. Capability traps? The mechanisms of persistent implementation failure. SSRN Electron. J. 2010, 234. [CrossRef]

41. Pandit, C.; Biswas, A.K. India's National Water Policy: 'Feel good'document, nothing more. Int. J. Water Resour. Dev. 2019, 35, 1015-1028. [CrossRef]

42. Wolf, A.T.; Newton, J.T. Case Study of Transboundary Dispute Resolution: The Indus Water Treaty; Department of Geosciences, Oregon State University: Corvallis, OR, USA, 2008.

43. Alam, A.R. A Constitutional History of Water in Pakistan; Jinnah Institute: Islamabad, Pakistan, 2019.

44. Akhter, M. Infrastructure nation: State space, hegemony, and hydraulic regionalism in Pakistan. Antipode 2015, 47, 849-870. [CrossRef]

45. Palijo, R.B. Sindh-Punjab Water Dispute; Center for Peace and Civil Society: Hyderabad, Pakistan, 2011.

46. Vander Velde, E.J.; Tirmizi, J. Irrigation Policy Reforms in Pakistan: Who's Getting the Process Right? In The Politics of Irrigation Reform; Ashgate Publishing Limited: Burlington, VT, USA, 2004; p. 239.

47. Alam Memon, J.; Mustafa, U. Emerging Issues in the Implementation of Irrigation and Drainage Sector Reforms in Sindh, Pakistan. Pak. Dev. Rev. 2012, 51, 289-301. [CrossRef]

48. Indus River Basin, Irrigation in Southern and Eastern Asia in Figures-AQUASTAT Survey-2011. Available online: http://www.fao.org/nr/water/aquastat/basins/indus/indusCP_eng.pdf (accessed on 24 March 2020).

49. Jabeen, A.; Huang, X.; Aamir, M. The challenges of water pollution, threat to public health, flaws of water Laws and Policies in Pakistan. J. Water Resour. Prot. 2015, 7, 1516. [CrossRef]

50. Events, F. International Regulation of Underwater Sound; Springer: Berlin/Heidelberg, Germany, 2004.

51. Birkland, T. Toward a Theory of Focusing Events and Policy Change, A Dissertation; 1994.

52. Cobb, R.W.; Elder, C.D. Participation in American Politics: The Dynamics of Agenda-Building; Johns Hopkins University Press: Baltimore, MD, USA, 1980.

53. Jenkins-Smith, H.; St Clair, G.K. The politics of offshore energy: Empirically testing the advocacy coalition framework. Policy Chang. Learn. 1993, 149-175.

54. Wasif, S. Pakistan may run dry by 2025: Study. The Express Tribune Pakistan, 30 May 2016.

55. National Water Policy 2018. Available online: http://mowr.gov.pk/wp-content/uploads/2018/06/NationalWater-policy-2018-2.pdf (accessed on 20 October 2019).

56. Rist, G. Development'as a part of the modern myth: The western 'socio-cultural dimension' of 'development. Eur. J. Dev. Res. 1990, 2, 10-21. [CrossRef]

57. Nandy, A. Science, Hegemony, and Violence: A Requiem for Modernity; Oxford University Press: Delhi, India, 1998.

58. Kothari, R. Rethinking Development: In Search of Humane Alternatives; Ajanta Publications: Delhi, India, 1988.

59. Constantino, R. Synthetic Culture and Development; Foundation for Nationalist Studies: Quezon City, Philippines, 1985.

60. Pieterse, J.N. After post-development. Third World Q. 2000, 21, 175-191. [CrossRef]

61. Lopez-Gunn, E. Agua Para Todos: A New Regionalist Hydraulic Paradigm in Spain. Water Altern. $2009,2,3$.

62. Khan, A.; Awan, N. Inter-Provincial Water Conflicts in Pakistan: A Critical Analysis. J. S. Asian Middle East. Stud. 2020, 43, 42-53.

63. Hassan, D.; Burian, S.J.; Bano, R.; Ahmed, W.; Arfan, M.; Rais, M.N.; Rafique, A.; Ansari, K. An Assessment of the Pakistan Water Apportionment Accord of 1991. Resourouse 2019, 8, 120. [CrossRef] 
64. Biswas, A.K. Integrated Water Resources Management: A Reassessment. Water Int. 2004, 29, $248-256$. [CrossRef]

65. Salik, K.M.; Hashmi, M.Z.-U.-R.; Ishfaq, S.; Zahdi, W.-U.-Z. Environmental flow requirements and impacts of climate change-induced river flow changes on ecology of the Indus Delta, Pakistan. Reg. Stud. Mar. Sci. 2016, 7, 185-195. [CrossRef]

66. Mahmood, Z. Kalabagh Dam: Sifting Fact from Fiction; Vanguard Books: New York, NY, USA, 2016.

67. Zahdi, Z.; Ishfaq, S. Ecological Assessment of the Indus Delta in Pakistan: A Desktop Analysis of Environmental Flow Requirements. Available online: https:/www.researchgate.net/profile/Waheed_Ul_Zahdi/ publication/287570996_Ecological_Assessment_of_the_Indus_Delta_in_Pakistan_A_Desktop_Analysis_ of_Environmental_Flow_Requirements/links/5677ab4c08ae125516edbc76.pdf (accessed on 12 January 2020).

68. Dinar, A. Policy implications from water pricing experiences in various countries. Hydrol. Res. 1998, 1, 239-250. [CrossRef]

69. Young, W.J.; Anwar, A.; Bhatti, T.; Borgomeo, E.; Davies, S.; Garthwaite, W.R., III; Saeed, B. Pakistan: Getting More from Water; World Bank: Washington, DC, USA, 2019.

70. Chandio, A.A.; Yuansheng, J.; Magsi, H. Agricultural Sub-Sectors Performance: An Analysis of Sector-Wise Share in Agriculture GDP of Pakistan. Int. J. Econ. Finance 2016, 8, 156. [CrossRef]

71. Commission, P. Canal Water Pricing for Irrigation in Pakistan: Assessment, Issues and Options; Government of Pakistan: Islamabad, Pakistan, 2012.

72. Sindh Irrigated Agriculture Productivity Enhancement Project. Available online: https://siapep.org/ (accessed on 12 February 2020).

73. Warner, J.F.; Hoogesteger, J.; Hidalgo, J.P. Old wine in new bottles: The adaptive capacity of the hydraulic mission in Ecuador. Water Altern. 2017, 10, 322-340.

74. Abu-Hatim, N.; Mohamed, A.S. Participatory irrigation management and cost-sharing in Yemen. In Water in the Arab World: Management Perspectives and Innovations; The World Bank: Washington, DC, USA, 2009.

75. Chaudhry, A.M. Improving on-farm water use efficiency: Role of collective action in irrigation management. Water Resour. Econ. 2017. [CrossRef]

76. Jacoby, H.G.; Mansuri, G. Governing the Commons? Water and Power in Pakistan's Indus Basin; The World Bank: Washington, DC, USA, 2018.

77. Jacoby, H.G.; Mansuri, G.; Fatima, F. Decentralization, and Redistribution: Irrigation Reform in Pakistan's Indus Basin; The World Bank: Washington, DC, USA, 2018.

78. Ahmad, B.; Pham, H.D.; Ashfaq, M.; Alam Memon, J.; Bano, R.; Dahri, Z.H.; Mustafa, R.N.; Baig, I.A.; Naseer, M.A.U.R. Impact of Institutional Features on the Overall Performance Assessment of Participatory Irrigation Management: Farmers' Response from Pakistan. Water 2020, 12, 497. [CrossRef]

79. Mustafa, D. Theory versus practice: The bureaucratic ethos of water resource management and administration in Pakistan. Contemp. South Asia 2002, 11, 39-56. [CrossRef]

80. Nagrah, A.; Chaudhry, A.M.; Giordano, M. Collective action in decentralized irrigation systems: Evidence from Pakistan. World Dev. 2016, 84, 282-298. [CrossRef]

81. El Ouaamari, S.; Garambois, N.; Fert, M.; Radzik, L. Development Assemblages and Collective Farmer-Led Irrigation in the Sahel: A Case Study from the Lower Delta of the Senegal River. Water Altern. 2019, 12, 68-87.

82. Liebrand, J. The politics of research on farmer-managed irrigation systems in Asia: Some reflections for Africa. Water Altern. 2019, 12, 129-145.

83. Mdee, A.; Harrison, E. Critical governance problems for farmer-led irrigation: Isomorphic mimicry and capability traps. Water Altern. 2019, 12, 30-45.

84. Ward, M.; Ali, M.; Mahar, Q.D. The Impact of Informal Institutions on Participatory Irrigation Management Outcomes; WSIP Report, in press.

85. IRSA Detects Misreporting by Sindh. Daily Dawn Newspaper. Available online: https://www.dawn.com/ news/1498651 (accessed on 30 March 2020).

86. Sindh Accused Punjab for Water Theft. Daily Nation Newspaper. Available online: https://nation.com.pk/09Jun-2014/punjab-accused-of-stealing-sindh-s-water (accessed on 30 March 2020).

87. Dinar, A.; Saleth, M.R. Water institutional reforms: Theory and practice. Water Policy 2005, 7, 1-19. 
88. Global Water Partnership. Setting the Stage for Change: Second Informal Survey by the GWP Network Giving the Status of the 2005 WSSD Target on National Integrated Water Resources Management and Water Efficiency Plans, 2006. Available online: http://waterwiki.net/images/9/9d/IWRMSurvey-final.pdf (accessed on 12 June 2016).

89. UN-Water. Status Report on IWRM and Water Efficiency Plans for CSD16; UN-Water: Geneva, Switzerland, 2008.

90. UN Environment Programme. The UN-Water Status Report on the Application of Integrated Approaches to Water Resources Management; UN Environment Programme: Nairobi, Kenya, 2012.

(C) 2020 by the authors. Licensee MDPI, Basel, Switzerland. This article is an open access article distributed under the terms and conditions of the Creative Commons Attribution (CC BY) license (http://creativecommons.org/licenses/by/4.0/). 